\title{
RESPONS MADRASAH TERHADAP GLOBALISASI
}

\section{Muhammad Thoyib}

STAIN Ponorogo Jl. Pramuka No. 156 Ronowijayan Ponorogo 63471

E-mail: thoyibmuhammad99@yahoo.co.id

\section{ABSTRAK}

Tulisan ini bermaksud menggali spirit globalisasi di madrasah. Analisis terhadapnya dilakukan melalui telaah kurikulum yang bersifat konseptual yang diasumsikan mengandung beberapa unsur globalisasi seperti demokrasi, otonomi, pasar internasional, unggul dan kompetitif. Pengembangan mutu madrasah yang berwawasan global diarahkan pada 4 kompetensi utama yaitu; kompetensi 1) akademik, 2) personal, 3) sosial dan 4) spiritual. Ia meliputi enam elemen yaitu; (1) pengetahuan dan kognitif, (2) pemahaman dan afektif, (3) kemampuan melaksanakan tugas atau pekerjaan dengan baik, (4) nilai, yaitu perilaku baik yang menyatu dalam diri seorang murid, (5) sikap, yaitu reaksi yang cepat terhadap rangsangan dari luar, serta (6) minat yang tinggi terhadap berbagai hal yang positif. Untuk menerapkan manajemen kurikulum yang berbasis globalisasi madrasah dapat mengaplikasikan strategi antara lain; 1) pengelolaan kurikulum secara mandiri, kreatif dan inovatif dengan semangat otonomi dan globalisasi; 2) menguasai ilmu pengetahuan, pembentukan pribadi, dan penguasaan kemampuan memecahkan masalah sosial kemasyarakatan; 3) menguasai kompetensi tertentu berdasarkan tahapan perkembangan peserta didik.

Kata Kunci: Madrasah, Globalisasi, Ungggul, Kompetitif

\section{ABSTRACT}

This paper intends to explore the spirit of globalization in the madrassa. The analysis is done through the study of conceptual curriculum which is assumed to contain some elements of globalization such as democracy, autonomy, international markets, superiority and competitiveness. The development of quality of madrassa with global orientation develop four main competencies: 1) academic, 2) personal, 3) social and 4) spiritual competencies. They cover six elements, namely: (1) knowledge and cognition, (2) understanding and affection, (3) the ability to execute a task or job well, (4) value, that covers good behavior behavior that manifest themselves in a pupil, (5) the attitude, is a fast reaction to external stimuli, and (6) bigh interest in the positive range. To implement curriculum based on globalization management, madrasas can apply strategies such as: 1) self-management curriculum, creative and innovative spirit of autonomy and globalization; 2) master of science, personal formation, and mastery of social problem-solving skills; 3) master developmentally specific competency based learners.

Keywords: Madrasa, Globalization, Superiority, Competitiveness 


\section{PENDAHULUAN}

Dalam era globalisasi dan pasar bebas, manusia dihadapkan pada perubahan-perubahan yang tidak menentu. Ibarat nelayan yang berada di "lautan lepas" yang setiap saat dapat tersesat jika tidak memiliki "kompas" sebagai pedoman untuk mengarunginya. Kondisi tersebut menimbulkan hubungan yang tidak selalu linier antara dunia pendidikan dengan lapangan kerja (one to one relationship). Kebutuhan dan tuntutan dunia kerja yang semakin berubah dengan cepat semakin sulit diikuti oleh dunia pendidikan. Itulah sebabnya direktur Pasipic Economic Cooperation menyatakan bahwa bangsa-bangsa di Asia Pasifik, termasuk Indonesia, perlu mempunyai pandangan ke luar dan ke depan (outward and forward looking) dalam menyelesaikan pelbagai masalah internal masyarakat dan bangsanya. Bagaimanapun juga, masyarakat dan bangsa Indonesia adalah bagian dari suatu masyarakat dunia yang semakin menyatu/global (Tilaar, 2001: 21).

Dalam konteks globalisasi, Jalal (2001: 27) mengemukakan bahwa pendidikan nasional Indonesia dihadapkan pada empat krisis pokok yang berkaitan dengan; (1) kuantitas, (2) relevansi atau efisiensi eksternal, (3) elitisme, dan (4) manajemen pendidikan. Empat krisis pokok tersebut tercermin dalam enam masalah utama sistem pendidikan nasional yakni; (1) menurunnya akhlak dan moral peserta didik, (2) pemerataan kesempatan belajar, (3) masih rendahnya efisiensi internal sistem pendidikan, (4) status kelembagaan, (5) manajemen pendidikan nasional yang tidak sejalan dengan pembangunan nasional, dan (6) sumber daya manusia yang belum profesional. Seiring dengan regulasi AFTA (Asian Free Trade Area), sejumlah lembaga pendidikan asing mulai membuka dan mendirikan sekolah maupun universitas internasional di Indonesia bahkan dengan perangkat manajemen pendidikan (kurikulum dan fasilitas pendidikan) yang lebih berkualitas. Mereka mulai mengalahkan reputasi sejumlah lembaga pendidikan ternama di Indonesia. Setiap saat mereka siap menghempaskan dunia pendidikan nasional manakala lembaga-lembaga pendidikan yang ada di Indonesia tidak kompetitif dan unggul. Seperti komoditi pangan, suatu saat semuanya menjadi serba impor. Mereka yang berada di daerah dan kurang memiliki akses terhadap informasi secara memadai (disinyalir masih lebih dari 53\% dari wilayah Indonesia) akan dengan lebih cepat termusiumkan.

Menghadapi hal di atas, perlu dilakukan penataan terhadap sistem pendidikan secara holistik yang di satu sisi melingkupi baik pendidikan umum (sekolah) maupun pendidikan keagamaan (madrasah) dan di sisi lain memperhitungkan kualitas dan relevansinya dengan kebutuhan masyarakat, dunia kerja serta tuntutan global. Pendidikan bukan semata-mata mempelajari berbagai hal yang ada dalam kehidupan tetapi ia adalah kehidupan itu sendiri. Untuk itu, kegiatan pendidikan sedemikian rupa dirancang agar dapat membekali peserta didik dengan berbagai kecakapan hidup yang sesuai dengan tuntutan lingkungan dan kebutuhan kehidupan global peserta didik. Latihan memecahkan masalah baik secara reflektif, kritis, demokratis, berkesinambungan maupun 
terencana secara matang perlu ditanamkan kepada peserta didik sejak dini termasuk juga kepada murid-murid di madrasah (Edward, 2007: 101).

UNESCO (1994) mengemukakan, ada dua prinsip pendidikan yang sangat relevan dengan Indonesian Nasional Educational Spirit (semangat pendidikan nasional Indonesia), pertama, pendidikan harus diletakan pada empat pilar; yaitu belajar mengetahui (learning to know), belajar melakukan (learning to do), belajar hidup dalam kebersamaan (learning to live together) dan belajar menjadi diri sendiri (learning to be); kedua, belajar seumur hidup (life long learning). Kultur akademis yang demikian itu harus dikembangkan ketika negara bermaksud membangun manusia Indonesia yang mampu bersaing dalam dunia yang semakin global. Aspek kultural manusia Indonesia yang selalu bersemangat untuk belajar mengetahui, mengamalkan, hidup bersama dengan orang yang berbeda tetapi berjati diri kuat, lebih penting dari pertumbuhan ekonomi dengan tanpa karakter/budaya yang kuat. Pendidikan adalah garda depan moralitas manusia Indonesia dalam dunia global yang penuh dengan kompetisi (Suyanto dan Hisyam, 2003: 54).

Tulisan ini bermaksud mengkaji sejumlah spirit globalisasi di madrasah. Metode analisis yang digunakan adalah analisis isi, yaitu dengan menganalisis secara kritis sejumlah literatur dan gejala globalisasi. Bidang pembahasan tulisan ini dibatasi melalui telaah kurikulum yang bersifat konseptual yang diasumsikan mengandung beberapa unsur globalisasi seperti konsep demokrasi, otonomi, pasar internasional, unggul dan kompetitif.

\section{PEMBAHASAN}

Diskursus globalisasi tercermin dalam al-Qur'an Surah Shâd [38]: 26 yang artinya; Hai Daud, sesungguhnya Kami menjadikan kamu khalifah (penguasa) di muka bumi, maka berilah keputusan (perkara) di antara manusia dengan adil dan janganlah kamu mengikuti hawa nafsu, karena ia akan menyesatkan kamu dari jalan Allah. Sesungguhnya orang-orang yang sesat dari jalan Allah akan mendapat adzab yang berat, karena mereka melupakan hari perhitungan (Digital Al-Quran versi 32 juz 23).

Ayat di atas menggambarkan bahwa ada seorang pemimpin (Nabi Dawud AS) yang menguasai wilayah tertentu. Dalam konteks negara dan bangsa, wilayah tersebut terepresentasikan dalam sebuah teritorial tertentu. Namun dalam ayat di atas tergambarkan bahwa teritorial yang dimaksud tidak saja berupa daerah dan batas wilayah yang dikuasai sebagaimana lazimnya sebuah negara dan bangsa namun seluruh wilayah yang disebut dengan bumi secara global bahkan dengan semua isinya. Berarti kisah tersebut mengisyaratkan bahwa pengertian wilayah teritorial itu sepadan dengan konsep global. Al Qur'an tidak merinci nama tempat dan negara tertentu. Ini merupakan karakter universalitas al-Qur'an yang untuk sementara waktu dapat ditafsirkan sebagai wujud sejalannya Islam dengan konsep globalisasi (Setiawan, 2012: 113-114). 
Dalam konteks globalisasi, manajemen kurikulum diorientasikan sebagai paradigma yang mengupayakan pembentukan sumber daya manusia Indonesia yang unggul dan kompetitif. Sifat unggul dan kompetitif tersebut merupakan tuntutan masyarakat global (abad 21) yang memiliki ciri-ciri yaitu; pertama, masyarakat cenderung bergaya hidup teknologis dan informatif (informasi sebagai sumber ekonomi dan dinikmati dalam rangka pemenuhan kebutuhan pokok hidup sehari-hari). Dalam arti ini, sadar atau tidak, mau atau tidak mau, Indonesia telah berada dalam pusaran arus budaya global yang meniscayakan bahwa umat manusia, dalam kehidupannya sangat mengandalkan teknologi informasi. Agar madrasah selalu up to date, seattle dan eksistensinya tetap terjaga, ia tidak boleh lari atau sembunyi dari kondisi ini. Sebaliknya, sebagai salah satu lembaga pendidikan dasar dan menengah bercirikan Islam Indonesia yang memiliki karakter dan sejarahnya sendiri, ia harus berupaya terus berkiprah dengan cara membuka diri sehingga dialektika globalisasi yang bersinergi dengan tuntutan kualitas betul-betul dijawab dengan lahirnya sejumlah lulusan madrasah yang unggul dan kompetitif. Kedua, masyarakat selalu menuntut keterbukaan. Berarti, madrasah harus akomodatif terhadap segala perkembangan yang terjadi, baik di lingkungan internal maupun eksternal lembaga tersebut. Ketiga, adanya kesadaran tentang pentingnya masyarakat madani (civil society). Artinya, madrasah harus mampu mendesain out put pendidikan yang tidak hanya tangguh dalam bidang pendidikan keagamaan Islam saja tetapi ia juga harus unggul dalam bidang ilmu pengetahuan dan teknologi terutama teknologi informasi serta memiliki karakter spiritualitas dan moralitas yang kuat dan bermanfaat. Semua ini merupakan ciri/karakteristik utama masyarakat madani di masa yang akan datang (Tilaar, 2001: 98 dan Sukmadinata, 1988: 17). Berdasarkan kenyataan ini, lingkungan global menjadi faktor penentu dalam menyusun, mengubah dan mengelola kurikulum sekolah/madrasah, sehingga perlu dibuat suatu konsep kurikulum sekolah/madrasah yang berbasis pada spirit globalisasi yaitu;

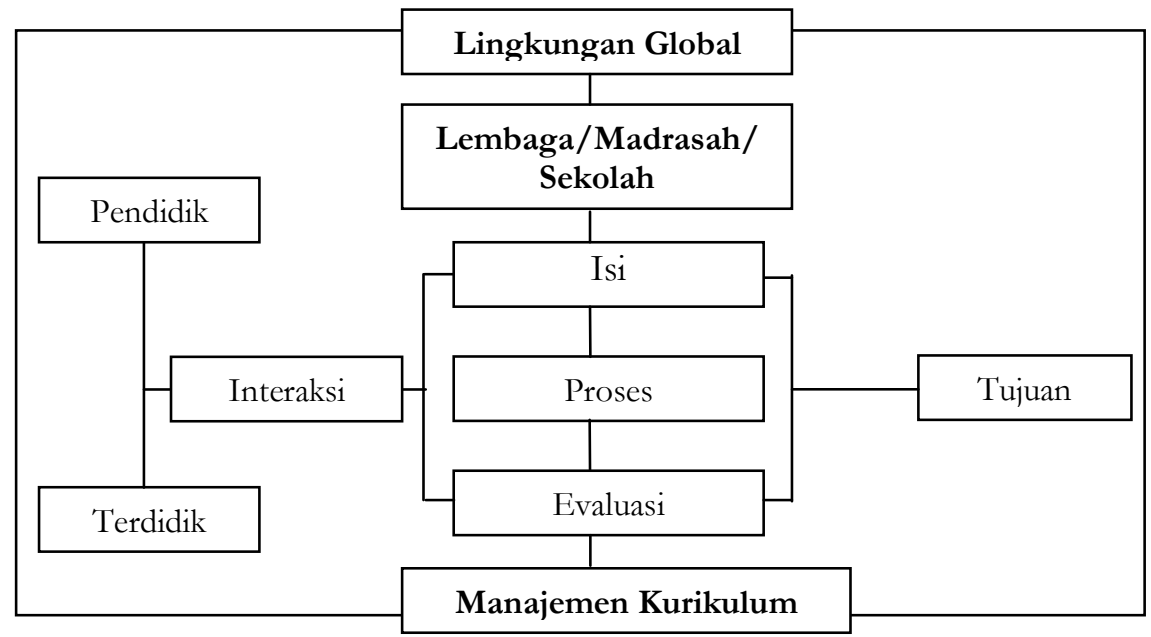


Komponen-komponen pendidikan sebagai isi dari kurikulum madrasah senantiasa dipengaruhi oleh lingkungan eksternal yang mengglobal. Isi (materi), metode, tujuan, proses, guru, anak didik, lingkungan sosial, ekonomi, budaya dan religi (agama) senantiasa ditempatkan dalam konteks kebutuhan dan tuntutan global. Hal itu berarti bahwa paradigma manajemen kurikulum merupakan suatu kesatuan dari komponen pendidikan yang saling mendukung serta menentukan keberhasilan implementasi program pendidikan di madrasah dalam kehidupan dewasa ini.

Agar dapat bersaing secara global, pengelolaan kurikulum pada dasarnya mengandung 4 sub bidang manajemen, sebagaimana dikonsepsikan oleh White (2008: 37), yaitu; (1) manajemen sumber daya manusia (berhubungan dengan pengelolaan SDM selaku pembuat dan pelaksana kurikulum serta pensukses aplikasinya bagi anak didik), (2) manejemen pembelajaran (berhubungan dengan pengelolaan dan penggunaan metode, materi dan proses pembelajaran yang tepat dan sesuai dengan kebutuhan anak didik dan kebutuhan masyarakat), (3) manajemen fasilitas (berhubungan dengan pengelolaan seluruh fasilitas pendidikan yang ada di sekolah) dan (4) manajemen penilaian (berhubungan dengan upaya evaluasi terhadap performa hasil dari pelaksanaan kurikulum di sekolah). Keempat sub bidang manajemen tersebut bersifat integratif, artinya saling mendukung, mempengaruhi dan menentukan keberhasilan pelaksanaan kurikulum di madrasah. Misalnya, materi kurikulum sudah baik, namun ketika tanpa didukung oleh pengelolaan sumber daya manusia (SDM) yang juga baik niscaya orientasi yang hendak dicapai oleh madrasah tidak akan dapat diwujudkan. Begitu juga dengan peran penilaian dalam mengukur sekaligus mengevaluasi sampai sejauh mana pencapaian yang telah diperoleh harus betulbetul dapat dimanfaatkan sebagai balikan (feed back) yang efektif. keempat sub bidang tersebut dengan manajemen kurikulum dapat dideskripsikan melalui skema di bawah ini;

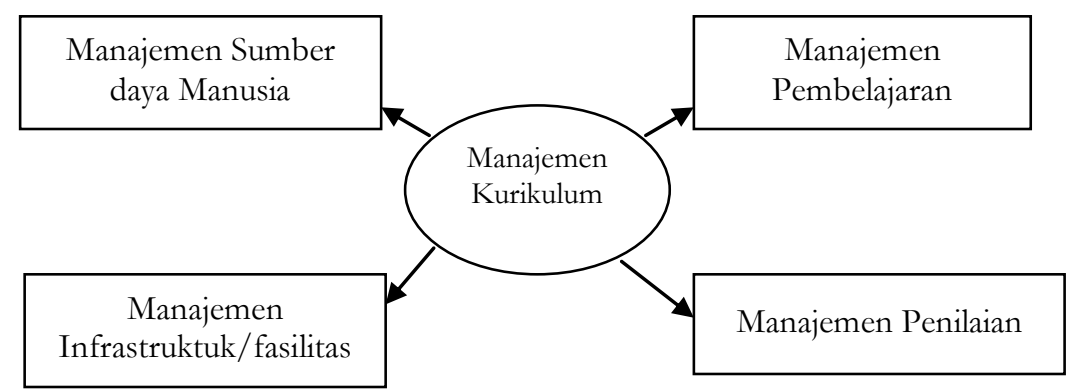

Secara normatif, idealnya setiap madrasah memiliki acuan kurikulum standar yang dapat dijadikan sebagai pedoman dalam mendesain kurikulum pendidikan di madrasah yang lebih bermutu dan memiliki nilai kompetitif. Tanpa adanya standarisasi kurikulum, akan sulit bagi sebuah sekolah akan mampu menghasilkan program pendidikan yang bermutu di madrasah. Indikasi 
kebermutuan kurikulum itu menurut Print (2010: 24) akan terlihat pada sejumlah hal; pertama, program pendidikan (pembelajaran dan kurikulum yang dihasilkan) sesuai dengan kebutuhan anak didik, guru dan masyarakat sebagai pengguna jasa pendidikan di madrasah. Kedua, kurikulum yang dirancang dapat diimplementasikan oleh para pendidikan dengan baik serta memiliki nilai balik (positiffeedback) yang positif di mana anak didik dapat merespons, memahami dan mengaplikasikan materi yang disampaikan kepadanya. Ketiga, dengan desain kurikulum tersebut masyarakat juga merespons secara positif ketika madrasah menghasilkan lulusan-lulusan yang bermutu dengan menggunakan jasa lulusannya sehingga dapat dikatakan bahwa kurikulum tersebut memiliki nilai yang bermutu dan kompetitif (having individual and social advantages). Nilai kebermutuan dan kompetitif dari suatu kurikulum menurut Mulyasa (2004: 70) haruslah tetap mengacu pada prinsip-prinsip kurikulum yang didasarkan berbagai aspek, baik individual, sosial maupun kebangsaan. Dalam bahasa penulis, pada disebut sebagai prinsip-prinsip kurikulum bermutu yaitu;

1. Keimanan, nilai dan budi pekerti. Prinsip tersebut dianut dan dijunjung tinggi masyarakat dan berpengaruh terhadap sikap dan arti kehidupannya.

2. Penguatan integritas nasional. Pengembangan kurikulum harus memperhatikan penguatan integritas nasional melalui pendidikan yang memberikan pemahaman tentang masyarakat Indonesia yang majemuk dan kemajuan peradaban dalam tatanan kehidupan dunia yang multikultural dan multibahasa.

3. Keseimbangan etika, logika, estetika dan kinestetika. Pengembangan kurikulum juga perlu memperhatikan keseimbangan pengalaman belajar peserta didik antara etika, logika, estetika, dan kinestetika.

4. Kesamaan memperoleh kesempatan. Pengembangan kurikulum harus menyediakan tempat yang memberdayakan semua peserta didik untuk memperoleh pengetahuan, keterampilan dan sikap perlu diutamakan dalam pengembangan kurikulum.

5. Abad teknologi informasi dan pengetahuan. Kurikulum perlu mengembangkan kemampuan berpikir dan belajar dengan mengakses, memilih dan menilai pengetahuan untuk mengatasi situasi yang cepat berubah dan penuh ketidakpastian, yang merupakan kompetensi penting dalam menghadapi abad ilmu pengetahuan dan teknologi informasi.

6. Pengembangan keterampilan untuk hidup (lifeskill). Pengembangan kurikulum perlu memasukkan unsur keterampilan untuk hidup agar peserta didik memiliki keterampilan, sikap dan perilaku adaptif, kooperatif dan kompetitif dalam menghadapi tantangan dan tuntutan kehidupan sehari-hari secara efektif.

7. Belajar sepanjang hayat. Pendidikan berlangsung sepanjang hidup manusia untuk mengembangkan, menambah kesadaran dan selalu 
belajar memahami dunia yang selalu berubah dalam berbagai bidang. Oleh karena itu, pengembangan kurikulum berbasis lifeskill perlu memperhatikan kemampuan belajar sepanjang hayat yang dapat dilakukan melalui pendidikan formal dan non-formal.

8. Berpusat pada anak dengan penilaian yang berkelanjutan dan komprehensif. Pengembangan kurikulum lifeskill harus berupaya memandirikan peserta didik untuk belajar, bekerja sama dan menilai diri sendiri agar mampu membangun pemahaman dan pengetahuannya.

9. Pendekatan menyeluruh dan kemitraan. Pengembangan kurikulum lifeskill dengan penguatan manajemen kurikulum harus mempertimbangkan semua pengalaman belajar yang dirancang secara berkesinambungan.

Menurut Edward (2007: 119) agar pengembangan kurikulum di madrasah dapat berjalan secara lebih efektif, madrasah perlu mendesain model pengembangannya supaya arah pengembangan kurikulum madrasah jelas dan memiliki nilai orientatif (tujuan) yang dapat meliputi seluruh kebutuhan peserta didik, masyarakat, sektor industri maupun tenaga pendidikan sendiri. Hal tersebut selaras dengan model pengembangan kurikulum menurut Tyler (1949). Menurutnya, setidaknya ada empat pertanyaan yang melandasi pengembangan kurikulum yaitu; (1) tujuan apa yang ingin dicapai sekolah?; (2) pengalamanpengalaman edukatif apa yang dapat diberikan agar tujuan itu dapat tercapai?; (3) bagaimana bahan itu harus diorganisasikan agar efektif?; (4) bagaimana dapat menentukan ketercapaian tujuan tersebut?. Keempat pertanyaan itu dapat dijadikan sebagai langkah-langkah dalam perencanaan kurikulum, yaitu (a) menentukan tujuan pendidikan; (b) menentukan proses pembelajaran; (c) menentukan organisasi kurikulum; (d) menentukan cara menilai hasil belajar (Nasution, 1993: 140).

Dalam hal menentukan tujuan pendidikan Islam/madrasah baiknya tidak hanya memperhitungkan pendapat para ahli disiplin ilmu yang berhubungan dengan mata pelajaran saja namun juga memperhatikan kebutuhan masyarakat yang selalu berkembang dan global. Pada umumnya masyarakat global menginginkan lulusan madrasah memiliki kualitas baik dalam penguasaan ilmu agama maupun ilmu umum secara integral. Dalam proses belajar mengajar, latar belakang pendidikan, pengalaman dan persepsi anak tentang Islam juga beragam. Keberagaman dalam pengetahuan tentang keberagamaan hendaknya menjadi dasar pengembangan kurikulum yang berbasis pada pluralisme aliran bahkan agama yang sangat dibutuhkan dalam mencipta generasi muda yang penuh toleran baik terhadap aliran maupun agama lain yang merupakan tuntutan budaya global. Membentuk generasi Islam yang moderat. Pengorganisasian kurikulum dengan cara broad field atau broad unit dapat mempunyai efek kumulatif maksimal terhadap penguasaan keterampilan maupun pengetahuan murid karena 
didasarkan pada evaluasi yang lebih bersifat deskriptif bukan normatif yakni dengan menggunakan sejumlah pengamatan atas hasil pekerjaan siswa (Nasution, 1993: 140-141). Keempat pertanyaan dan urutan penyusunan kurikulum di atas landasan filosofis dan psikologis tertentu yaitu;

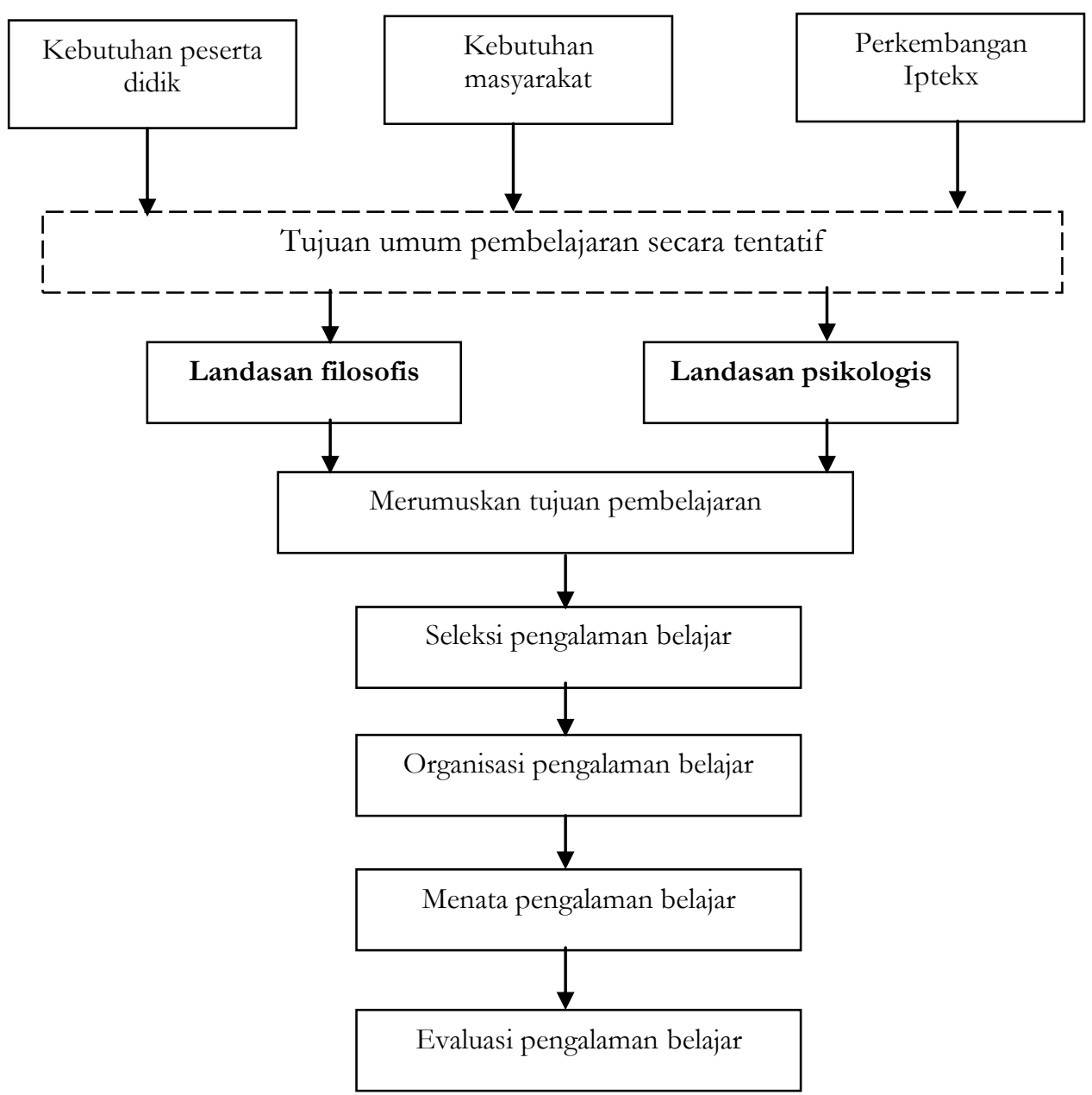

Dalam konteks madrasah, pengembangan kurikulum menurut Tyler memperhitungkan utamanya landasan filosofis dan psikologis madrasah yang bersumber pada ajaran Islam universal dan juga global. Misalnya, secara filosofis, pendidikan madrasah tidak hanya berdimensi duniawi semata tetapi juga berdimensi akhirat. Implikasinya, secara filosofis pendidikan madrasah senantiasa mengindahkan dialektika dunia dan akhirat. Anak didik senantiasa diajarkan untuk selalu menjadi manusia yang sesungguhnya, dalam arti selalu beramal saleh, berakhlak mulia dan beriman kepada Allah swt. 
Secara normatif, madrasah aliyah internasional merupakan madrasah percontohan yang telah mampu mengantar anak didiknya ke gerbang kesuksesan seperti halnya studi ke luar negeri seperti ke Mesir, Sudan, Maroko, Inggris, Australia dan Jepang. Dua di antara madrasah tersebut adalah MAN Insan Cendekia Tangerang dan MAN 2 Kediri. Keduanya memiliki prestise tersendiri dengan adanya beasiswa. Mereka juga memiliki orientasi pengembangan manajemen kurikulumnya dalam rangka memelihara kualitas dan kompetensi out put-nya (lulusan) agar senantiasa sesuai dengan kebutuhan perkembangan zaman serta kompetisi internasional.

Dalam konteks aplikasi manajemen kurikulumnya, madrasah internasional berorientasi pada pengembangan 4 kompetensi fundamental, yaitu kompetensi akademik, kompetensi personal, kompetensi sosial dan kompetensi spiritual. Keempat kompetensi tersebut menjadi penekanan utama madrasah, baik ditujukan kepada performa guru maupun siswa khususnya secara seimbang di mana subtansi kompetensi itu mencakup sejumlah komponen. Hal ini sejalan dengan konsep kurikulum yang digagas oleh Skillbeck (2009: 91-92) yang meliputi; (1) pengetahuan (knowledge); yaitu kesadaran dalam bidang kognitif, (2) pemahaman (understanding), yaitu kedalaman kognitif dan afektif yang dimiliki individu, (3) kemampuan (skill), yang merupakan sesuatu yang dimiliki individu untuk melakukan tugas atau pekerjaan yang dibebankan kepadanya, (4) nilai (value), yaitu suatu standar perilaku yang telah diyakini dan secara psikologis telah menyatu dalam diri seseorang, (5) sikap (attitude), yaitu menyangkut perasaan atau reaksi terhadap suatu rangsangan yang datang dari luar, serta (6) minat yang menyangkut kecenderungan seseorang untuk melakukan sesuatu perbuatan.

Upaya pencapaian keseimbangan kompetensi itu mutlak dilakukan karena madrasah aliyah tersebut merupakan miniatur lembaga pendidikan Islam yang berupaya mewujudkan insan-insan Muslim yang kaffah, yang tidak hanya memiliki kemampuan di bidang ilmu pengetahuan sebagai prasyarat utama persaingan global, tetapi juga memiliki kepekaan sosial, rasa kemanusiaan serta kepribadian religius yang bersendikan kepada moralitas nilai-nilai agama. Hal ini senada dengan apa yang ditegaskan oleh Thomas (2005: 7) bahwa untuk menghadapi kompetisi global yang syarat akan arus negatif globalisasi, tidak cukup bagi seseorang hanya dengan memiliki modal sosial berupa penguasaan ilmu pengetahuan dan teknologi, tetapi lebih dari itu, ia juga harus memiliki rasa kemanusiaan dan moralitas yang tinggi agar mampu mengantisipasi ekses-ekses negatif globalisasi sehingga tidak terjerumus dalam lembah kenistaan, serta memiliki rasa kepercayaan diri yang kuat agar anak didik tidak mengalami goncangan kebudayaan (culture shock) atas intensitas kompetisi yang begitu tinggi dan kuat.

Dalam konteks pencapaian keseimbangan itu, madrasah aliyah internasional pada aspek kurikulumnya berupaya menyeimbangkan kebutuhan antara materi umum dan agama serta ditunjang oleh sejumlah materi keterampilan ekstrakurikuler seperti otomotif, komputer dan study club for foreign 
language. Sedangkan pada aspek metode pembelajarannya diupayakan keaktifan siswa secara penuh di mana siswa diorientasikan sebagai aktor utama kesuksesan pembelajaran (student centered learning for the success) di madrasah, seperti misalnya; praktik berbahasa asing sehari-hari dengan mendatangkan native speaker, serta praktik sejumlah keterampilan atau kerajinan tangan.

Ada sejumlah strategi peningkatan manajemen kurikulum lifeskill dalam rangka pengembangan mutu SDM yang unggul dan kompetitif yang dapat diaplikasikan oleh madrasah aliyah internasional yaitu; Dilihat dari pengelolaannya, manajemen kurikulum dibedakan antara sistem pengelolaan yang terpusat (sentralisasi) dan tersebar (desentralisasi). Kurikulum pendidikan dasar dan menengah tahun 1968 dan 1975 bersifat sentralistik, hanya ada satu kurikulum untuk satu jenis pendidikan di seluruh Indonesia. Kurikulum ini bersifat nasional, seragam, dikembangkan oleh tim pusat, guru-guru hanya berperan sebagai pelaksana di madrasah, yakni menjabarkan rencana tahunan, caturwulan dan satuan pelajaran tiap pelajaran. Dalam kurikulum 1984 telah ada muatan lokal yang disisipkan pada berbagai bidang studi yang sesuai, dan hal ini lebih diintensifkan lagi pelaksanaannya dalam kurikulum 1994. Dalam kurikulum 1994 muatan lokal tidak lagi disisipkan pada setiap bidang studi, tetapi menggunakan pendekatan monolitik berupa bidang studi, baik bidang studi wajib maupun pilihan.

Dengan adanya kebijakan otonomi daerah, muatan lokal dialokasikan lebih besar. Modelnya lebih beragam dan sistemnya tidak terpusat lagi sehingga pengelolaannya menjadi desentralisasi. Idealnya perimbangan muatan nasional dengan daerah antara, 25\% sampai dengan $40 \%$ untuk muatan nasional dan $60 \%$ sampai dengan $75 \%$ untuk muatan daerah. Dengan bobot muatan daerah/lokal yang lebih besar berarti pengembangan kurikulum lebih banyak dilakukan oleh tim pengembang yang terdiri atas para ahli dan guru-guru di daerah. Kurikulum juga akan lebih banyak diwarnai oleh unggulan daerah, baik kekayaan, perkembangan maupun kebutuhan daerah. Model kurikulumnya akan beragam sesuai dengan tujuan, fungsi dan isi program pendidikan. Pengembangan kurikulum menjadi lebih berbasis daerah atau kewilayahan. Kurikulum yang demikian ada yang menyebutnya kurikulum berbasis masyarakat, ada juga yang menyebutnya kurikulum berbasis madrasah.

Berdasarkan fokus dan sasarannya, peningkatan manajemen kurikulum dibedakan antara pendekatan yang mengutamakan penguasaan ilmu pengetahuan, penguasaan kemampuan standar, penguasaan kompetensi, pembentukan pribadi dan penguasaan kemampuan memecahkan masalah sosial kemasyarakatan. Pertama, pendekatan penguasaan ilmu pengetahuan, merupakan model pengembangan kurikulum yang menekankan pada isi atau materi, berupa pengetahuan, pemahaman, aplikasi, analisis, sintesis, dan evaluasi yang diambil dari bidang-bidang ilmu pengetahuan.

Kedua, pendekatan kemampuan standar yang menekankan pada penguasaan kemampuan potensial yang dimiliki peserta didik sesuai dengan 
tahap-tahap perkembangannya. Ketiga, pendekatan pembentukan pribadi, menekankan pada pengembangan atau pembentukan aspek-aspek kepribadian secara utuh, baik pengetahuan, keterampilan maupun nilai dan sikap. Dalam pelaksanaannya para pengembang kurikulum ini banyak memberikan perhatian terhadap aspek-aspek sosial-emosional. Keempat, pendekatan pemecahan masalah (problem solving) kemasyarakatan, diarahkan pada terciptanya masyarakat yang lebih baik. Pengembangan kurikulumnya menekankan pada pengembangan kemampuan memecahkan masalah-masalah penting dan mendesak yang ada di masyarakat. Pendekatan ini banyak dilakukan dalam manajemen kurikulum pendidikan luar madrasah. Kelima, pendekatan kompetensi, merupakan model peningkatan manajemen kurikulum yang menekankan pada pemahaman, kemampuan atau kompetensi tertentu di madrasah, yang berkaitan dengan pekerjaan yang ada di masyarakat.

Dalam hubungan dengan pendekatan kompetensi, kurikulum 2013 juga merupakan kurikulum yang berbasis kompetensi. Kurikulum ini direncanakan oleh Kementerian Pendidikan dan Kebudayaan Republik Indonesia diberlakukan pada bulan Juli 2013. Dalam kurikulum tersebut tidak lagi tegas adanya penjurusan tetapi lebih mengarah kepada peminatan. Siswa memiliki kebebasan mengembangkan minatnya (Kompas, 25-1-2013: 12).

Kurikulum yang berbasis kompetensi merupakan pendekatan peningkatan manajemen kurikulum yang memokuskan pada penguasaan kompetensi tertentu berdasarkan tahap-tahap perkembangan peserta didik. Peserta didik berada dalam proses perkembangan yang berkelanjutan dari seluruh aspek kepribadian, sebagai pemekaran terhadap potensi-potensi bawaan sesuai dengan kesempatan belajar yang ada dan diberikan oleh lingkungan. Setiap tahap perkembangan memiliki sejumlah potensi bawaan yang dapat dikembangkan, tetapi pemekarannya sangat tergantung pada kesempatan yang ada dan kondisi lingkungannya. Setiap peserta didik memiliki potensi bawaan sendiri-sendiri meskipun aspek-aspek perkembangannya sama tetapi tingkatannya berbeda. Seorang peserta didik memiliki kemampuan berpikir matematis yang tinggi, tetapi peserta didik lain berpikir ekonomi politik, keterampilan sosial, atau komunikasi yang tinggi. Guru-guru diharapkan dapat mengenali dan memahami potensi-potensi, terutama potensi-potensi tinggi yang dimiliki peserta didiknya. Dengan bekal pemahaman tersebut, mereka diharapkan dapat membantu mengembangkan potensi-potensi peserta didik sehingga dapat berkembang secara optimal.

Untuk kepentingan kesuksesan strategi dan efektivitas pelaksanaan manajemen kurikulum, pimpinan madrasah harus mampu memobilisasi sumber daya madrasah yang berkaitan dengan beberapa hal penting (Mulyasa, 2004: 183); pertama, perencanaan dan evaluasi program madrasah. Madrasah diberi kewenangan untuk melakukan perencanaan sesuai dengan kebutuhannya (schoolbased plan), seperti kebutuhan untuk meningkatkan mutu madrasah. Oleh karena itu, madrasah harus melakukan analisis kebutuhan mutu untuk mengembangkan 
rencana peningkatan mutu. Dalam konteks itu, madrasah diberi kewenangan untuk melakukan evaluasi, khususnya evaluasi yang dilakukan secara internal. Evaluasi internal atau sering juga disebut evaluasi diri dilakukan oleh warga madrasah untuk memantau proses pelaksanaan dan mengevaluasi hasil programprogram yang telah dilaksanakan.

Kedua, pengembangan kurikulum berbasis kompetensi guna mendukung secara maksimal pencapaian kebutuhan lifeskill bagi anak didik di madrasah nantinya dapat memberikan kewenangan kepada daerah dan madrasah untuk mengidentifikasi kompetensi dan mengembangkan silabus sesuai dengan keutuhan daerah, kebutuhan dan karakteristik peserta didik. Ketiga, pengembangan pembelajaran. Proses pembelajaran merupakan interaksi edukatif antara peserta didik dengan lingkungan madrasah. Dalam hal ini madrasah diberi kebebasan untuk memilih strategi, metode, dan teknik-teknik pembelajaran yang paling efektif, sesuai dengan karakteristik mata pelajaran, karakteristik siswa, karakteristik guru, dan kondisi nyata sumber daya yang tersedia di madrasah.

Keempat, pengelolaan ketenagaan. Pengelolaan ketenagaan, mulai dari analisis kebutuhan, perencanaan, rekrutmen, pengembangan, reward dan sangsi (punishment), hubungan kerja, sampai evaluasi kinerja tenaga kerja madrasah (guru, tenaga administrasi, dan laboran) dapat dilakukan oleh madrasah, kecuali yang menyangkut penggajian atau upah dan rekrutmen guru pegawai negeri, yang sampai saat ini ditangani oleh birokrasi di atasnya. Kelima, pengelolaan sarana dan sumber belajar. Pengelolaan sarana dan sumber belajar sudah sewajarnya dilakukan oleh madrasah, mulai dari pengadaan, pemeliharaan dan perbaikan hingga sampai pengembangan. Hal ini didasari oleh kenyataan bahwa madrasahlah yang paling mengetahui kebutuhan sarana dan sumber belajar, baik kecukupan, kesesuaian, maupun kemutakhirannya, terutama sumber-sumber belajar yang dirancang (by design) secara khusus untuk kepentingan kesuksesan pembelajaran anak didiknya.

Keenam, pengelolaan keuangan. Pengelolaan keuangan terutama pengalokasian atau penggunaan uang sudah sepantasnya dilakukan oleh madrasah. Hal ini juga didasari oleh kenyataan bahwa sekolahlah yang paling memahami kebutuhannya, sehingga desentralisasi pengalokasian dan penggunaan uang dilimpahkan ke madrasah. Madrasah diberi kebebasan untuk melakukan kegiatan-kegiatan yang mendatangkan penghasilan (income generating activities) sehingga sumber keuangan tidak semata-mata bergantung pada pemerintah. Ketujuh, pelayanan siswa. Pelayanan siswa mulai dari penerimaan siswa baru, pengembangan, pembinaan, pembimbingan, penempatan untuk melanjutkan pendidikan, sampai memasuki dunia kerja, sepenuhnya merupakan kewenangan madrasah yang menuntut kemampuan kepala madrasah untuk mengembangkannya.

Kedelapan, hubungan madrasah dengan masyarakat. Hakekat hubungan madrasah dengan masyarakat adalah untuk meningkatkan keterlibatan, kepedulian, kepemilikan, dan dukungan dari masyarakat terutama dukungan 
moral dan finansial. Dalam implementasi manajemen kurikulum itu, hubungan madrasah dengan masyarakat tersebut perlu ditingkatkan terutama untuk mengembangkan potensi-potensi yang dimiliki oleh madrasah terutama potensipotensi lulusan yang akan dihasilkannya. Kesembilan, penciptaan iklim madrasah. Iklim madrasah (fisik dan non fisik) yang kondusif-akademik merupakan prasyarat bagi terselenggaranya implementasi manajemen kurikulum secara lebih efektif. Lingkungan madrasah yang aman dan tertib, optimisme dan harapan yang tinggi dari warga madrasah, kesehatan madrasah, dan kegiatan-kegiatan yang terpusat pada siswa (student-centered activities) merupakan iklim madrasah yang dapat menumbuhkan semangat belajar siswa.

Namun demikian ada sejumlah kehawatiran terhadap pelaksanaan kurikulum 2013. Berarti kehawatiran terhadap pelaksanaan tersebut secara teori lebih mengarah pada persoalan manajemen kurikulum bukan substansi kurikulum. Persiapan yang dilakukan dalam hitungan bulan (kurang dari setahun), secara teori tidak cukup jika tujuannya adalah mengubah kurikulum dari Kurikulum Tingkat Satuan Pendidikan menjadi Kurikulum 2013 yang berbasis kompetensi. Memang kurikulum 2013 pernah digagas dalam rintisan Kurikulum Berbasis Kompetensi (KBK) pada tahun 2004. Akan tetapi pelaksanaan dan evaluasi terhadap kurikulum tersebut tidak dilakukan dengan jelas dan transparan serta terkesan terburu-buru seperti halnya sekarang ini. Unsur terpenting dalam pengelolaan terhadap apa pun adalah perencanaan. Dalam manajemen strategik unsur perencanaan ini menjadi elemen yang utama. Environmental scanning (analisis lingkungan) baik secara eksternal maupun internal menjadi modal utama dalam menentukan misi sebuah program. Dengan demikian ketika sebuah program dirancang, misalnya 'perubahan kurikulum' diperlukan sebuah riset yang hasilnya dapat dipetakan dalam SWOT (Strengths, Weaknesses, Oportunities and Threats) yakni kekuatan, kelemahan, peluang dan tantagan (Hunger and Wheelen, 1993: 12-13).

Dalam kurikulum yang berbasis kompetensi seperti kurikulum 2013 ini selalu ada yang disebut dengan kompetensi inti. Kompetensi inti bukan diajarkan melalui pembelajaran tetapi dibentuk seluruh elemen yang berhubungan dengan proses pembelajaran. Oleh karena itu, ketercapaian kompetensi inti memerlukan waktu yang panjang (Nuh dalam Kompas, 7 Maret 2013: 6). Salah satu konsep yang relevan dengan pencapaian kompetensi inti adalah konsep lifeskill. Keberhasilan peningkatan manajemen kurikulum lifes kill bagi peningkatan mutu SDM terutama lulusan yang akan dihasilkan setidak-tidaknya memberikan beberapa indikator positif (Mulyasa, 1999: 34);

1. Adanya peningkatan mutu pendidikan yang dapat dicapai oleh madrasah melalui kemandirian dan inisiatif kepala madrasah dan guru dalam mengelola dan mendayagunakan sumber-sumber yang tersedia.

2. Adanya peningkatan efisiensi dan efektivitas pengelolaan dan penggunaan sumber-sumber pendidikan melalui pembagian tanggungjawab yang jelas, tranparan dan demokratis. 
3. Adanya peningkatan perhatian serta partisipasi warga dan masyarakat sekitar madrasah dalam penyelenggaraan pendidikan dan pembelajaran yang dicapai melalui pengambilan keputusan bersama.

4. Adanya peningkatan tanggungjawab madrasah kepada pemerintah, orangtua peserta didik, dan masyarakat pada umumnya berkaitan dengan mutu madrasah, baik dalam intra maupun ekstra kurikuler.

5. Adanya kompetisi yang sehat antar madrasah, siswa maupun tenaga guru dan administratif dalam peningkatan mutu pendidikan melalui upaya-upaya inovatif dengan dukungan orang tua peserta didik, masyarakat, dan pemerintah daerah setempat.

6. Tumbuhnya kemandirian dan berkurangnya ketergantungan di kalangan warga madrasah, bersifat adaptif dan proaktif serta memiliki jiwa kewirausahaan tinggi (ulet, inovatif dan berani mengambil resiko).

7. Terwujudnya proses pembelajaran yang efektif, yang lebih menekankan pada belajar mengetahui (learning to know), belajar berkarya (learning to do), belajar menjadi diri sendiri (learning to be), dan belajar hidup bersama secara harmonis (learning to live together).

8. Terciptanya iklim madrasah yang aman, nyaman dan tertib, sehingga proses pembelajaran dapat berlangsung dengan tenang dan menyenangkan (enjoyble learning).

Secara substantif ada perbedaan sudut pandang antara KTSP (2006) dengan KBK (2004 dan 2013). Kurikulum Tingkat Satuan Pendidikan lebih berbasis kepada penguasaan materi sedangkan Kurikulum Berbasis Kompetensi berbasis kepada pembentukan kemampuan inti yang harus miliki oleh siswa termasuk kecakapan dalam mempelajari hidup. Dalam konteks madrasah kompetensi hidup memiliki identitasnya sendiri terutama bagi madrasah yang berbasis pesantren. Integrasi antara madrasah/pesantren dengan masyarakat yang sudah menyejarah dan karakter pondok/pengasramaan (dalam bahasa globalnya adalah boarding school pesantren harus betul-betul menjadi dasar pembentukan kurikulum madrasah yang berbasis globalisasi.

Adanya proses evaluasi dan perbaikan dilakukan secara berkelanjutan. Evaluasi belajar secara teratur bukan hanya ditujukan untuk mengetahui tingkat daya serap dan kemampuan peserta didik, tetapi untuk memanfaatkan hasil evaluasi belajar tersebut bagi perbaikan dan penyempurnaan proses pembelajaran di madrasah. Allah SWT senantiasa menguji manusia, tinggal mencari jawab; "Siapa di antara kamu yang lebib baik amalnya?" (Q.S. Al-Mulk [67]: 2).

\section{SIMPULAN}

Orientasi atau tujuan penting yang ingin dicapai dari manajemen kurikulum yang berbasis globalisasi adalah menyiapkan murid yang tidak gagap dengan perkembangan zaman bahkan seharusnya bisa mengubah dalam arti memperbaiki keadaan zaman ke arah yang lebih baik. Agar dapat memperbaiki 
zaman maka murid harus dikenalkan dengan karakter zaman itu sendiri yang global ini. Beberapa konsep seperti unggul, kompetitif, lifeskill dan bermutu merupakan konsep yang mewakili keadaan zaman yang global. Dalam konteks pengembangan mutu SDM yang berorientasi pada pemenuhan global terutama out put nya, di madrasah aliyah yang berwawasan global dikembangkan 4 kompetensi utama; kompetensi akademik, personal, sosial dan spiritual yang mencakup sejumlah elemen kompetensi yang meliputi; (1) pengetahuan (knowledge); yaitu kesadaran dalam bidang kognitif, (2) pemahaman (understanding), yaitu kedalaman kognitif dan afektif yang dimiliki individu, (3) kemampuan (skill), yang merupakan sesuatu yang dimiliki individu untuk melakukan tugas atau pekerjaan yang dibebankan kepadanya, (4) nilai (values), yaitu suatu standar perilaku yang telah diyakini dan secara psikologis telah menyatu dalam diri seseorang, (5) sikap (attitude), yaitu menyangkut perasaan atau reaksi terhadap suatu rangsangan yang datang dari luar, serta (6) minat yang menyangkut kecenderungan seseorang untuk melakukan sesuatu perbuatan. Untuk menerapkan manajemen kurikulum yang berbasis globalisasi yang ditandai dengan out put yang unggul dan kompetitif, madrasah dapat mengaplikasikan sejumlah strategi antara lain; 1) strategi berdasarkan pendekatan sistem pengelolaan di mana harus ditekankan pada pengelolaan kurikulum secara mandiri, kreatif dan inovatif oleh madrasah sesuai dengan semangat otonomi (spirit of otonomy). 2) strategi berdasarkan pendekatan fokus sasaran yang meliputi aspek penguasaan ilmu pengetahuan, penguasaan kemampuan standar, penguasaan kompetensi, pembentukan pribadi, dan penguasaan kemampuan memecahkan masalah sosial kemasyarakatan anak didik. 3) strategi berdasarkan pendekatan kompetensi memokuskan pada penguasaan kompetensi tertentu berdasarkan tahap-tahap perkembangan peserta didik. Keberhasilan strategi itu harus didukung pula oleh kemampuan pimpinan madrasah untuk memobilisasi potensi sumber daya yang ada di madrasah tersebut.

\section{DAFTAR PUSTAKA}

Digital Al Qur'an Versi 3.2.

Edward, Philip. 2007. Management and Curriculum in Education: Concept and Practice. New York: Prenhall Ltd.

Hunger, David, J and Wheelen, L, Thomas. 1993. Strategic Management. USA: Addison-Wesley Publishing Company, Inc.

Jalal, Fasli (editor), dkk. 2001. Reformasi Pendidikan dalam Konteks Otonomi Daerah. Yogyakarta: Adicita \& Depdiknas.

Kompas. 2013. Edisi 25 Januari.

Kompas. 2013. Edisi 7 Maret.

Mulyasa.E. 2004. Kurikulum Berbasis Kompetensi: Konsep, Karakteristike dan Implementasi. Bandung: Rosdakarya. 1999. Pedoman Pemahaman dan Penerapan Kurikulum Muatan Kurikulum di Sekolah Dasar. Bandung: Geger Sunten. 
Maslow, A. 1970. Motivation and Personality. New York: Harper and Row.

Nasution, 1993. Pengembangan Kurikulum. Bandung: Citra Aditya Bakti.

Print, Murray. 2010. Curriculum Development and Design. Sidney: Allen and Unwin. :

Setiawan, Nur Kholis. M. 2012. Pribumisasi Al Qur'an. Yogyakarta. Kaukaba Dipantara.

Sukmadinata, Nana Syaodih. 1988. Prinsip dan Landasan Pengembangan Kurikulum. Jakarta: P2LPTK Depdikbud.

Skillbeck, Malcolm. 2009. School Based Curriculum Development and Teacher Education. Mimeograph: OECD.

Suyanto dan Djihad Hisyam. 2003. Refleksi dan Reformasi Pendidikan di Indonesia Memasuki Milenium III. Yogyakarta: Adicita.

Thomas, J. Alan. 2005. The Productive School: A System Analisys Approach to Educational Administration. Chichago University: Tt.

Tilaar, H.A.R. 2001.Manajemen Pendidikan Nasional: Kaj̈an Pendidikan Masa Depan Bandung: . Remaja Rosdakarya.

White, John. 2008. International Curriculum and Its Great Purpose. Kogan Page: Educational Studies. 